\title{
Öz Yeterliğin İş Özerkliği Üzerindeki Etkisi: Turist Rehberleri Üzerine Bir Araştırma
}

\section{The Effect of Self-Efficacy on Job Autonomy: A Research on Tourist Guides}

\author{
Öğr. Gör. Esra KATIRCIOĞLU \\ Dumlupınar Üniversitesi, Simav Meslek Yüksekokulu, Türkiye \\ Dumlupınar University, Simav Vocational School, Turkey \\ E-Mail: esra.yilmaz@dpu.edu.tr \\ Arş. Gör. Ali KABAKULAK \\ Afyon Kocatepe Üniversitesi, Turizm Fakültesi, Türkiye \\ Afyon Kocatepe University, Tourism Faculty, Turkey
}

E-Mail: alikabakulak@aku.edu.tr

$\ddot{O} z$

Amaç ve Önem: Bu çalışmanın temel amacı turist rehberlerinin öz yeterlik seviyelerinin iş özerkliği algıları üzerindeki etkisini incelemektir. Çalışma kapsamında ayrıca turist rehberlerinin öz yeterlik seviyeleri ile iş özerkliği algılarının belirlenmesi hedeflenmektedir. Turist rehberliği mesleğinin özellikleri dikkate alındığında, öz yeterlik ve iş özerkliği kavramlarının, mesleğin uygulanabilirliği açısından önemli olduğu düşünülmektedir.

Yöntem: Çalışmada nicel araştırma yöntemlerinden anket tekniği kullanılmıştır. Bu kapsamda eylemli turist rehberlerinin doldurması için Google formlar programı aracıllğı ile çevrimiçi anket oluşturulmuş ve rehberlerden çalışmaya katılmaları istenmiştir.

Bulgular: Araştırmada turist rehberlerinin öz yeterliklerinin iyi seviyede olduğu, iş özerkliklerinin iyi seviyeye yakın olduğu; öz yeterlikle iş özerkliği arasında pozitif, orta düzeyde ve anlamlı bir ilişki bulunmuştur. Ayrıca turist rehberlerinin öz yeterliği ile iş özerkliği arasındaki regresyon modeli üzerinde etkisi olduğu ortaya çıkmıştır.

Özgünlük/Bilimsel Katkı: Yapılan literatür taramasında, turist rehberlerinin öz yeterlikleri üzerine yapılan sınırlı sayıda çalışmaya ulaşılmıştır. Aynı zamanda turist rehberlerinin yalnızca öz yeterlikleri ile iş özerkliklerine odaklanan çalışmaya rastlanamamıştır. Ayrıca turist rehberlerinin öz yeterliklerinin iş özerklikleri üzerindeki etkinin ilgili taraflarca (Tureb, Türsab, Kültür ve Turizm Bakanlığ 1 vd.) bilinmesi, turist rehberlerinin istihdamı ve yönettikleri turlarda sağlayacakları memnuniyet üzerindeki etkisinin yanı sıra ülkenin veya bölgenin bilinirliğine de önemli katkı sağlayacağından bu bağlamda ileride oluşturulacak politikalara fikir vermesi açısından önemli bir katkı sağlayacağı düşünülmektedir. Bunun yanı sıra turist rehberlerinin özerk ve bağımsız çalışabilmesinin tur deneyimi, kalitesi, sunum ve hizmet verme isteği gibi konularda önemli katkılar sağlayacağı da düşünülmektedir.

Çalışmanın Sınırıııkları: Çalışma kapsamında, Türkiye'nin yedi farklı coğrafi bölgesine dağılmış halde olan on üç turist rehberleri odasına ulaşmanın zaman ve maliyet açısından mümkün olamaması bu çalışmanın sınırlılıklarından bir tanesidir. Ayrıca turist rehberlerinin çalışmaya katılmaya istekli olmayışları çalışmanın diğer bir sınırlılığı olarak ifade edilebilir. Çalışma kapsamında rehberlere çevrimiçi anketler aracılı̆ğ ile ulaşılmaya çalışmıştır.

Anahtar Kelimeler: Turist rehberleri, öz yeterlik, iş özerkliği.

Makale Türü: Araştırma makalesi

Atıf için (for cited); Katırcıoğlu, E. ve Kabakulak, A. (2020). Öz Yeterliğin İş Özerkliği Üzerindeki Etkisi: Turist Rehberleri Üzerine Bir Araştırma, Turist Rehberliği Dergisi, 3(1), 32-43. 
Turist Rehberliği Dergisi (TURED) \& Yıl. 2020, Cilt. 3, Sayı. 1

Journal of Tour Guiding (JOTOG) \& Year. 2020, Volume. 3, Issue. 1

\begin{abstract}
Purpose and Importance: The main purpose of this study is to examine the effect of tourist guides' self-efficacy levels on their job autonomy perceptions. Within the scope of the study, it is also aimed to determine the self-efficacy levels and job autonomy perceptions of tourist guides. Considering the characteristics of the tourist guidance profession, the concepts of self-efficacy and job autonomy are considered important variables for the applicability of the profession.
\end{abstract}

Methodology: Questionnaire technique, which is one of the quantitative research methods, was used in the study. In this context, an online questionnaire was created through Google forms program to be fulfilled by the tourist guides, and the guides were asked to participate in the study.

Findings: In this research, tourist guides' self-efficacy level is good, and their job autonomy perception is close to good. A positive, moderate and significant relationship was found between self-efficacy and job autonomy. It has also been revealed in regression model that tourist guides' self-efficacy levels have an impact on their job autonomy perceptions.

Originality/Value: In the literature review, a limited number of studies on tourist guides' self-efficacy have been reached. Also, there has been no study focusing solely on tourist guides 'self-efficacy and job autonomy. Besides tourist guides' self-efficacy levels have an effect on their job autonomy. Being explicitly known by the interested parties (Tureb, Tursab, Ministry of Culture and Tourism, etc.), that will contribute significantly to the awareness of the country or the region, as well as its impact on the employment and satisfaction of tourist guides in the tours they manage. It is thought to make an important contribution in terms of giving ideas to policies. In addition to these, tourist guides' autonomous and independent work will make important contributions in such matters as tour experience, quality, desire to provide presentation and service, etc.

Research Limitations/ Implications: One of the limitation of the study is that it has not been possible to reach 13 chamber of tourist guides located in seven different regions of Turkey as it would be costly and time consuming. In addition, tourist guides' unwillingness is another limitation as an online questionnaire has been used in order to collect data.

Keywords: Self efficacy, job autonomy, tourist guides.

Paper Type: Research article

Giriş

Turizm endüstrisinin sınır birim elemanları arasında yer alan turist rehberleri (Lin vd., 2008: 1265; Tsaur ve Lin, 2014: 28) ziyaret edilen destinasyonun yerli halk1 ile turistler arasındaki ilişkide arabulucu görevi üstlenmektedir (Ap ve Wong, 2001: 551). Ziyaretçilere kendi tercih ettikleri dilde rehberlik eden ve belirli bir bölgeye ait kültürel ve doğal mirası yorumlama yetki ve becerisine sahip olan turist rehberleri (WFTGA, 2020); turistlerin ziyaret ettikleri destinasyon ile ilgili tatmin ve izlenimleri üzerinde de etkili olan aynı zamanda turistik bir ziyareti deneyime dönüştürebilme becerisine sahip kimselerdir (Reisinger ve Steiner, 2006: 483). Liderlik ettikleri grupların izlenimleri, deneyimleri hatta duygusal değişimleri üzerinde bu denli etkili olan turist rehberlerinin nitelikleri ve profesyonellikleri son derece önemli bir konudur. Nihayet, turist rehberlerinin ziyaretçilere sunulan cazibe unsuru ile ilgili pozitif bir imaj oluşturması ve bunu devam ettirebilmesi gerekmektedir (Pratiwi vd., 2019: 175). Bunu başarabilmenin yolu da turistlerin çok çeşitli talep ve beklentilerine karşı rehberlerinin her zaman hazırlıklı olabilmelerinden geçmektedir. Dolayısıyla, turist rehberlerinin daima kendilerini yenilemeleri; bilgi, beceri ve yetkinlik açısından kişisel gelişimlerine katkıda bulunmaları yani öz yeterliklerini geliştirmeleri gerekmektedir.

Öz yeterlik, bireylerin olası durumları ön görme, eylem planları organize etme ve yönetme becerilerine olan inançları olarak tanımlanmaktadır (Pajares, 1996: 544). Turist 
rehberleri açısından değerlendirildiği takdirde bu durum, rehberlerin turlarda ortaya çıkması muhtemel sorunları ön görebilmesi ve gerekli tedbirleri alarak turu yönetebilmesi, müşteri memnuniyeti sağlayabilmesi, acentanın güveni kazanarak çalışılan gün sayısının arttırabilmesi ve rehberlik mesleğinden daha fazla kazanç sağlayarak olumlu mesleki tutum ve iş doyumuna katkı sağlayabileceği düşünülmektedir. Öz yeterliliğin yanı sıra bağımsız çalışma durumu da turist rehberleri için turun iyi geçmesi, daha kaliteli hizmet verebilmeleri ve sunum yapabilmelerinin yanı sıra turu daha iyi idare edebilmeleri açısından son derece önemlidir. Yoğun rekabetin olduğu dinamik ortamlarda, çalışanlara özerklik sağlanması çevresel taleplere cevap vermenin anahtarı olarak görülmektedir (Hakimi, van Knippenberg ve Giessner, 2010). Bu bağlamda, rehberler açısından, prosedürleri ve kuralları titizlikle takip etmek müşterilerin sorunlarını çözmek ve ihtiyaçlarını karşılamak için yeterli değildir (Bowen ve Lawler, 1992; Hartline, Maxham ve McKee, 2000). Bunun yanı sıra rehberlerin bağımsız ve özgür bir biçimde çalışabilmeleri de gereklidir. Gray ve Pratt (1989) ile Hart ve Rotem (1995) özerkliğin profesyonel gelişmenin önemli bir parçası olduğunu; Blegen (1993) ise özerkliğin bağımsız olarak icra edilen mesleklerde iş doyumu üzerinde pozitif etkisi olduğunu ifade etmişlerdir. İş memnuniyeti ve motivasyon gibi önemli örgütsel çıktılara katkıları olan iş özerkliği, iş tasarımının kritik özelliklerinden bir tanesi olarak tanımlanmıştır (Hackman ve Oldham, 1980; akt. Sousa, Coelho ve Guillamon-Saorin, 2012). Bu nedenle mesleğini bireysel olarak icra eden turist rehberleri için bağımsız hareket etme, özerk olma olmazsa olmazdır.

Turist rehberlerinin kişilik özelliklerinden benlik algısına ait öz yeterlik seviyelerinin iş özerkliği üzerinde etkili olduğu varsayımından hareketle çalışmanın temel amacı turist rehberlerinin öz yeterlik seviyelerinin iş özerklikleri üzerindeki etkisini incelemek olarak belirlenmiştir.

\section{Kuramsal Çerçeve}

Son yıllarda turizm sektöründe yaşanan olumlu gelişmeler ülke ekonomilerine olumlu katkılar sağlamaktadır. Dünya çapında ülkelerin büyük bir çoğunluğu, ekonomilerindeki açığı kapatma, istihdam yaratma ve ülkelerindeki yer altı ve yer üstü zenginliklerini tanıtma ve sahip oldukları turizm arz unsurların pazarlama gayretindedirler. Sahip olunan arz unsurlarının tanıtılması ve pazarlanması farklı kanallarla (internet siteleri, sosyal medya araçları, radyo, TV kanalları ve programları vb.) yapılabilmektedir. Bahsedilen iletişim araçları, yapılan tanıtımlar aracılığıyla bireylerde çekicilikleri görme isteği uyandırabilmektedirler. Bu nedenle kişiler, paket turlar satın alarak turizm faaliyetlerine katılabilirler. Ancak tam olarak gidilecek destinasyon (ülke, bölge, yöre vb.), yerel halkın özellikleri ve gelenek görenekleri hakkında çok az bilgi sahibi olabilirler. Bu nedenle seyahate katılan turistlere ülke, bölge, yerel halk, yaşam standartları, gelenek ve görenekler, adet ve ritüeller gibi konularda en iyi hizmeti verebilecek ve destinasyon ile ilgili etkili tanıtımlar yapabilecek kişiler turist rehberleridir. Turist rehberi, turistlerle iletişimi ilk kuran, turistlerin ülkeden ayrılışına kadar turistlerin her türlü sorun ve istekleriyle uğraşan aslında ülke ile ilgili ilk izlenimi sağlayan kişidir. $\mathrm{Bu}$ nedenle turist rehberlerinin kendilerini iyi yetiştirmesi, bilgili ve donanımlı olması, liderlik edebilmesi ve turu yönetebilmesi temel yeterlilikler arasında en öne çıkmaktadır. Bu açıdan bakıldığında, turist rehberlerinin öz yeterliklerinin belli bir seviyede olması gerekmektedir.

Öz yeterlik, "bireylerin yaşamlarındaki olayları kontrol edebilmek için gerekli olan bilişsel, güdüsel ve davranışsal kaynaklara ve gerektiğinde bu kaynakları harekete geçirebilecek kapasiteye sahip olduklarına olan inançları" olarak ifade edilmektedir (Şahin ve Gürbüz, 2012: 128). Bandura (1997) tarafından bireylerin belli davranışları sergileyebilmeleri için bir takım aktiviteleri organize edebilmeleri ve davranışı başarılı bir biçimde yapabilmelerine ilişkin kendilerine yönelik yargıları olarak tanımlanan öz yeterlik, 
davranışların oluşumu için gerekli görülmektedir (Aşkar ve Umay, 2001: 1). Öz yeterlik, kişiliğe atfedilen pasif bir özellikten ziyade benliği oluşturan diğer değişkenlerin bir bileşkesi durumundadır. Dolayısıyla öz yeterliği eksik olan kişilerde, diğer insanlar üzerinde etkisi olmayan davranışlar gözlemlenebilmektedir (Üstüner vd., 2009: 2). Griffin vd. (2007: 336) bireylerin öz yeterlik seviyeleri, kendileri hakkında beklenti, özgüven ve belirli bir davranış1 yapabilme kapasitesine yönelik yargıları belirlemektedir. Bu nedenle öz yeterlik seviyesi yüksek olan kişiler proaktif davranışlar sergileme eğiliminde olup; daha iyi performans göstermektedirler. Öz yeterlik proaktif davranışının önemli belirleyicileri arasında yer almaktadır. Bunun nedeni, yeteneklerine güven duyan bireylerin yaptıkları faaliyetlerin başarılı olacağına dair inançları yüksektir (Morrison ve Phelps, 1999: 406). Turist rehberlerinde de durum aynıdır. Eğer bir turist rehberi kendi yeteneklerine inanmıyorsa ve kendine güvenmiyorsa böyle birinin turu yönetme ve başarılı olma şansı yok denecek kadar azdır. Acentalar, birlikte çalıştıkları turist rehberlerinin öz yeterliklerinin, yeteneklerinin ve öz güvenlerinin yüksek olmasını beklerler.

Öz yeterlik, acentalar ve diğer işverenler tarafindan turist rehberlerinden beklenen önemli bir gereklilikken, yapılan işin niteliğine göre rehbere özerklik tanınması da turist rehberlerinin acentalar ve diğer işverenlerden bekledikleri bir iş gereğidir. Turist rehberliği mesleği tek başına icra edilen bir meslektir. Bu nedenle turist rehberleri tura başlayıp bitirene kadar aldıkları kararlarda ve yaptıkları seçimlerde özgür olmayı isterler. Bunun nedeni sürekli sözü kesilen, kararları sorgulanan, dışarıdan sürekli bask1 altında tutulan, konaklama konusunda dahi belli zorunluluklar dâhilinde çalışan bir turist rehberi bağımsız davranamadığ için etkili bir sunum yapamaz, grup hâkimiyeti oluşturamaz ve en önemlisi de yaptı̆̆ işsten keyif alamaz. Bu durumun doğal bir sonucu olarak da turist rehberleri iş doyumsuzluğu yaşayarak bir süre sonra başladığı turu yarıda bırakmak durumunda kalabilirler. Bu nedenle işi süresince bağımsız olmak, özgür hareket edebilmek turist rehberliği mesleğinin icrasını daha etkili ve kaliteli hale getireceğinden özerklik konusuna işverenlerin çok daha fazla özen göstermesi önemlidir.

Turner ve Lawrence (1965) iş özerkliğini, çalışandan tebliğ edilen görevi yerine getirirken kullanması beklenen takdir yetkisi olarak tanımlamaktadırlar (Breaugh, 1999). Hackman ve Oldham (1975) özerkliği iş özellikleri kuramı çerçevesinde ele almışlar ve özerkliği; "görevin, işin planlanmasında ve yürütülmesinde kullanılacak prosedürlerin belirlenmesinde önemli ölçüde özgürlük, bağımsızlık ve takdir yetkisi sağlaması"” olarak tanımlanmışlardır (Hackman ve Oldham, 1975: 162). Özerklik, çalışanların tatminini, bağlılığını ve motivasyonunu etkileyen önemli bir iş özelliğidir (Spector, 1986: 1015). Özerkliğin, iş projelerini seçebilme, bir işin nasıl yapılacağına karar verebilme ve iş programlarını oluşturabilme konusunda yeterince özgür olmak anlamı taşıması, kavramın önemi açısından bilgi verici mahiyettedir. Nihayet kurumsal başarı açısından iş özerkliği (Amburgey, 2005) üzerinde önemle durulan bir olgudur.

\section{Araştırmanın Amacı ve Önemi/Hipotezi}

$\mathrm{Bu}$ araştırmanın temel amacı turist rehberlerinin öz yeterlik seviyelerinin özerklik algıları üzerindeki etkisini tespit etmektir. $\mathrm{Bu}$ doğrultuda çalışma kapsamında turist rehberlerinin öz yeterlik seviyeleri ve özerklik algıları belirlenmiştir. Araştırma kapsamında literatür taraması yapılmış ve bu tarama sonucunda turizm alanında öz yeterlikle ilgili çalışmalar (Turamberk Özerden, 2010; Akgündüz 2012; Ercan, 2014; Sarı, 2017; Keskin, 2017; Kendir, 2017; Eryılmaz, 2018; Uçar, 2018; Aksoy, 2019) gerçekleştirildiği saptanmıştır. Yapılan çalışmalar konaklama işletmelerindeki otel çalışanları, yöneticiler ve rekreatif etkinliklere katılan bireyler üzerine yapıldığı görülmüştür. İş özerkliği açısından 
incelendiğinde turizm sektöründe yapılmış sınırlı çalışmaya (Yılmaz, 2018) rastlanmıştır. Bu araştırmada konaklama işletmelerinde çalışanların iş özerklikleri incelenmiştir. Genel olarak incelendiğinde öz yeterlik ve iş özerkliklerinin konaklama sektörü çalışanları üzerine gerçekleştiği anlaşılmaktadır. Ancak, araştırma değişkenleri öz yeterlik ile iş özerkliği açısından incelendiğinde turist rehberleri üzerine sinırlı çalışmaya rastlanmıştır. Bu sınırlı çalışmalarda Çınar (2018) turizm rehberliği bölümü öğrencilerinin genel öz yeterlik algısını ölçmüştür. Diğer çalışmada ise Ulusoy (2017) turist rehberlerinin kültürel zekâ ve öz yeterlik inançlarının hizmet sunuma etkisini incelemiştir. Ancak daha önce turist rehberlerinin öz yeterlikleri ile iş özerkliklerini birlikte ele alan herhangi bir çalışmaya rastlanmamıştır. Dolayısıyla bu alandaki boşluğu doldurmak ve turist rehberlerinin öz yeterlikleri ile iş özerkliklerini ortaya koymak amacıyla bu araştırma kapsamında aşağıda yer alan hipotez geliştirilmiştir.

$\mathrm{H}_{1}$ : Turist rehberlerinin öz yeterlik algıları iş özerklik algılarını anlamlı düzeyde pozitif yönde etkilemektedir.

\section{Yöntem}

Araştırmada öncelikle öz yeterlik ve iş özerkliği değişkenleriyle ilgili literatür taraması yapılmış ve elde edilen sonuçlar/çıkarımlar doğrultusunda kuramsal çerçeve oluşturulmuştur. Uygulama aşamasında nicel veri toplama yöntemlerinden anket tekniğinden faydalanılmıştır. Uygulanan anket üç bölümden oluşmaktadır. Anket formu rehberlerin demografik özelliklerini belirlemeye yönelik sorular ile öz yeterlik seviyelerini ve özerklik algılarını ölçmeye yönelik ölçeklerden oluşmaktadır. İlk bölümde turist rehberlerinin demografik özelliklerini ölçmek (cinsiyet, medeni durum, yaş, deneyim süresi, aylık gelir) amacıyla turist rehberlerine kapalı uçlu 5 soru yöneltilmiştir.

İkinci bölümde, öz yeterlik ölçeği yer almaktadır. Bosscher ve Smit (1998), genel öz yeterlik ölçeğini kişinin çeşitli durumlarda sonuçları etkileme potansiyeline ve kişisel yeteneklerine ilişkin algıladığ 1 yeterlik inancını değerlendirmek üzere tasarlamışlardır. Genel öz yeterlik ölçeği, toplamda 3 boyut (girişimcilik, gayret ve kararlılık) ve 12 maddeden oluşmaktadır. Bosscher ve Smit (1998) tarafından oluş̧urulan ölçek Tarakçı (2009) tarafından ulusal literatüre kazandırılmış; Uçar (2018) tarafından ölçeğin genel güvenirliği 0,69 olarak belirlenmiştir.

Son bölümde yer alan özerklik ölçeği ise, Dude (2012) tarafindan doktora çalışması kapsamında kullanılmıştır. Ölçeğin maddeleri Türkçe 'ye uyarlanarak kullanılmıştır. Dude (2012) tarafından yapılan çalışmada ölçeğin 4 madde ve tek boyut, Cronbach Alpha katsayısı ise 0,777 olarak belirlenmiştir. Çalışmada kullanılan tüm ölçekler kesinlikle katılmıyorum (1), katılmıyorum (2), orta düzeyde katılıyorum (3), katılıyorum (4) ve kesinlikle katılıyorum (5) şeklinde 5'li Likert derecelendirmesi şeklinde oluşturulmuştur.

Araştırmanın kapsamı yalnızca eylemli turist rehberleri ile sınırlandırılmıştır. TUREB (2020) verileri doğrultusunda 13 farklı meslek odasına kayıtlı toplam rehber sayısının 11059 olduğu belirlenmiştir. Bunların 8053 tanesi eylemli olarak turist rehberliği mesleğini icra etmektedirler. Zaman, maliyet ve ulaşılabilirlik unsurları göz önünde bulundurulduğunda, Türkiye'de faaliyet gösteren tüm turist rehberlerine ulaşmanın mümkün olamayacağı düşüncesiyle evrenden belirli bir örneklemden anket tekniği ile veri toplanmıştır. Araştırmada kolayda örnekleme yöntemi kullanılmıştır. Veriler, 1 Ocak- 29 Şubat 2020 tarihleri arasında toplanmıştır. Bu kapsamda Google forms programı aracılığıyla online anket oluşturulmuş ve turist rehberlerine anket linki sosyal medya uygulamaları üzerinden yollanmıştır. Ayrıca 13 rehber odasına anket linki yollanmış ve üye rehberlerle online anket linkinin paylaşılması 
Turist Rehberliği Dergisi (TURED) \& Yıl. 2020, Cilt. 3, Sayı. 1

Journal of Tour Guiding (JOTOG) \& Year. 2020, Volume. 3, Issue. 1

istenmiştir. Bununla birlikte, turist rehberlerine bireysel olarak telefon ile ulaşılmış ve anketlerin hem kendileri hem de tanıdıkları eylemli turist rehberleriyle paylaşmaları talep edilmiştir. Bu kapsamda online anketler vasıtasıyla 250 turist rehberine anket linki yollanmış ve telefonla ulaşılmıştır, ancak 138 turist rehberinden veri toplanabilmiştir. Dolayısıyla araştırmanın örneklemi 138 eylemli turist rehberinden oluşmaktadır.

\section{Bulgular}

Araştırma kapsamında elde edilen veriler SPSS paket programı kullanılarak bilgisayar ortamında analiz edilmiştir. Araştırmada ilk olarak turist rehberlerine ait demografik özellikleri içeren frekans ve yüzde dağılımları, yine öz yeterlik ve iş özerklikleri ölçekleri/algılarına yönelik yüzde-frekans dağılımları ile ortalama ve standart sapma değerleri verilerek yorumlanmıştır. Turist rehberlerinin öz yeterlikleri ile iş özerklikleri arasındaki ilişkiyi belirlemek için korelasyon; öz yeterliklerinin iş özerklikleri üzerindeki etkisinin belirlenmesine yönelik regresyon analizi uygulanmıştır. Araştırmanın takip eden bölümünde, araştırma verilerine uygulanan analizlerden elde edilen bulgulara ve yorumlarına yer verilmiştir.

Tablo 1'de Türkiye'de eylemli olarak çalışan turist rehberlerinin demografik özelliklerine ilişkin bulgular sunulmuştur. Tablo 1'e göre araştırmaya katılan eylemli turist rehberlerinin, \%55,8'i erkek, \%44,2'si kadındır. Katılımc1ların \%49,3'ü evli, \%50,7'si bekârdır. Araştırmaya katılan turist rehberlerinin yaş grupları incelendiğinde sırasıyla, 29-40 yaş arası $(\% 50,0), 20-28$ yaş arası $(\% 23,2), 51$ yaş ve üzeri $(\% 16,7), 41-50$ yaş arası $(\% 10,1)$ şeklinde ortaya çıkmıştır. Araştırmaya katılan eylemli turist rehberlerinin deneyim süreleri incelendiğinde sırasıyla 8-14 y1l (\%35,5), 2-7 y1l $(\% 23,2), 1$ y1l ve daha az $(\% 22,5)$ ve 15 y1l ve üzeri $(\% 18,8)$ deneyime sahip oldukları belirlenmiştir. Katılımcıların gelir durumlarına göre dağılımı 4501 TL ve üzeri (\%37,7), 0-2324 TL (\%33,3), 2325-3500 TL (\%16,7), 35014500 TL $(\% 12,3)$ gelir sağladıkları saptanmıştır.

Tablo 1: Katılımcıların Demografik Özelliklerine İlişkin Bulgular

\begin{tabular}{|c|c|c|c|c|c|c|c|}
\hline \multicolumn{2}{|c|}{ Bireysel Değişkenler } & f & $\%$ & \multicolumn{2}{|c|}{ Bireysel Değişkenler } & f & $\%$ \\
\hline \multirow{2}{*}{ Cinsiyet } & Kadın & 61 & 44,2 & \multirow{4}{*}{ Deneyim } & 1 Yil ve daha az & 31 & 22,5 \\
\hline & Erkek & 77 & 55,8 & & 2-7 Yil & 32 & 23,2 \\
\hline \multirow{2}{*}{ Medeni Durum } & Evli & 68 & 49,3 & & 8-14 Y11 & 49 & 35,5 \\
\hline & Bekâr & 70 & 50,7 & & $15+Y_{11}$ & 26 & 18,8 \\
\hline \multirow{4}{*}{ Yaş } & $20-28$ & 32 & 23,2 & \multirow{4}{*}{ Gelir } & $0-2324 \mathrm{TL}$ & 46 & 33,3 \\
\hline & $29-40$ & 69 & 50,0 & & $2325-3500 \mathrm{TL}$ & 23 & 16,7 \\
\hline & $41-50$ & 14 & 10,1 & & $3501-4500 \mathrm{TL}$ & 17 & 12,3 \\
\hline & $51+$ & 23 & 16,7 & & 4501 ve üzeri & 52 & 37,7 \\
\hline
\end{tabular}

Güvenilirlik analizlerine ilişkin iç tutarlılık kat sayıları Cronbach's Alpha $(\alpha)$ kat sayıları hesaplanarak analiz edilmiştir. İş özerkliği ölçeğine ilişkin güvenilirlik kat sayısı 0,722 olarak hesaplanmıştır. Dude (2012) tarafından yapılan çalışmada özerklik ölçeğine ilişkin güvenilirlik kat sayısı 0,777 olarak bulunmuştur. Bu çalışmanın sonucu, Dude'nin (2012) çalışmasının sonucu ile benzerlik göstermektedir. Öz yeterlik ölçeğine ilişkin güvenilirlik kat sayıs1 ise 0,860 olarak hesaplanmıştır. Ulusoy'un (2017) yapmış olduğu araştırmada, öz yeterlik ölçeğine ilişkin güvenilirlik kat sayısı 0,71 olarak tespit edilmiş olup; bu çalışmadaki sonuca yakın bir sonuç bulunmuştur. Kalaycı (2017: 405) güvenilirlik kat sayısını alfa kat sayısına bağlı olarak yorumlamış ve $0,60 \leq \alpha \leq 0.80$ ise ölçek oldukça güvenilir; $0.80 \leq \alpha \leq$ 1.00 ise ölçek oldukça yüksek düzeyde güvenilir şeklinde yorumlamıştır. Bu bilgiye dayanarak öz yeterlik ve özerklik ölçekleri için güvenilirlik düzeylerinin oldukça yüksek olduğu gözlemlenmiştir. 
Turist Rehberliği Dergisi (TURED) \& Yıl. 2020, Cilt. 3, Sayı. 1

Journal of Tour Guiding (JOTOG) \& Year. 2020, Volume. 3, Issue. 1

Turist rehberlerinin öz yeterliklerini belirlemeye yönelik uygulanan ölçekteki her bir ifadeye ilişkin frekans ve yüzde dağılımları ile aritmetik ortalama ve standart sapma değerleri Tablo 2'de yer almaktadır. Ayrıca bazı ifadeler ters kodlanarak analizler yapılmıştır. Ters kodlanan ifadeler $(\mathrm{T})$ şeklinde tabloda gösterilmiştir.

Tablo 2: Katılımcıların Öz Yeterlik Ölçeğine İlişkin Katılım Düzeyleri

\begin{tabular}{|c|c|c|c|c|c|c|c|c|}
\hline Öz Yeterlik Ölçeği & 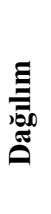 & 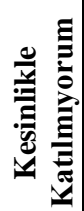 & 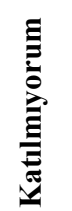 & 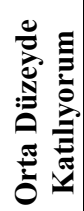 & E & 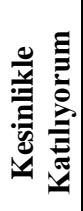 & $\bar{X}$ & ss. \\
\hline \multirow{2}{*}{$\begin{array}{l}\text { Eğer bir şey çok karmaşık görünürse denemeye bile } \\
\text { yeltenmem. }(T)\end{array}$} & $\mathrm{f}$ & 10 & 17 & 23 & 32 & 56 & \multirow{2}{*}{3,78} & \multirow{2}{*}{1,29} \\
\hline & $\%$ & 7,2 & 12,3 & 16,7 & 23,2 & 40,6 & & \\
\hline \multirow{2}{*}{$\begin{array}{l}\text { Çok zor görünen yeni şeyleri öğrenmeye } \\
\text { çalışmaktan kaçınırım. (T) }\end{array}$} & $\mathrm{f}$ & 5 & 13 & 14 & 31 & 75 & \multirow{2}{*}{4,14} & \multirow{2}{*}{1,15} \\
\hline & $\%$ & 3,6 & 9,4 & 10,1 & 22,5 & 54,3 & & \\
\hline \multirow{2}{*}{$\begin{array}{l}\text { Yeni bir şey öğrenmeye çalışırken, eğer başlangıçta } \\
\text { başarılı olmazsam hemen vazgeçerim. }\end{array}$} & $\mathrm{f}$ & 8 & 11 & 15 & 24 & 80 & \multirow{2}{*}{4,14} & \multirow{2}{*}{1,23} \\
\hline & $\%$ & 5,8 & 8,0 & 10,9 & 17,4 & 58,0 & & \\
\hline \multirow{2}{*}{$\begin{array}{l}\text { Plan yaptığımda, o planı hayata geçirebileceğimden } \\
\text { eminimdir. }\end{array}$} & $\mathrm{f}$ & 1 & 9 & 27 & 46 & 55 & \multirow{2}{*}{4,05} & \multirow{2}{*}{0,96} \\
\hline & $\%$ & 0,7 & 6,5 & 19,6 & 33,3 & 39,9 & & \\
\hline \multirow{2}{*}{$\begin{array}{l}\text { Eğer bir işi ilk denemede yapamazsam başarana } \\
\text { kadar denemeye devam ederim. }\end{array}$} & $\mathrm{f}$ & 2 & 11 & 19 & 41 & 65 & \multirow{2}{*}{4,13} & \multirow{2}{*}{1,02} \\
\hline & $\%$ & 1,4 & 8,0 & 13,8 & 29,7 & 47,1 & & \\
\hline \multirow{2}{*}{$\begin{array}{l}\text { Hoşlanmadığım bir şeyi yapmak durumunda } \\
\text { kaldığımda bitirene kadar o işte ısrarcı olurum. }\end{array}$} & $\mathrm{f}$ & 14 & 20 & 35 & 32 & 37 & \multirow{2}{*}{3,42} & \multirow{2}{*}{1,30} \\
\hline & $\%$ & 10,1 & 14,5 & 25,4 & 23,2 & 26,8 & & \\
\hline \multirow{2}{*}{$\begin{array}{l}\text { Bir şey yapmaya karar verdiğimde doğrudan o iş } \\
\text { üzerinde çalışmaya başlarım. }\end{array}$} & $\mathrm{f}$ & 1 & 7 & 20 & 37 & 73 & \multirow{2}{*}{4,26} & \multirow{2}{*}{0,93} \\
\hline & $\%$ & 0,7 & 5,1 & 14,5 & 26,8 & 52,9 & & \\
\hline \multirow{2}{*}{$\begin{array}{l}\text { Başarısızlık beni sadece daha azimli bir şekilde } \\
\text { denemeye yöneltir. }\end{array}$} & $\mathrm{f}$ & 5 & 6 & 33 & 33 & 61 & \multirow{2}{*}{4,01} & \multirow{2}{*}{1,02} \\
\hline & $\%$ & 3,6 & 4,3 & 23,9 & 23,9 & 44,2 & & \\
\hline \multirow{2}{*}{$\begin{array}{l}\text { Kendim için önemli hedefler belirlediğimde bu } \\
\text { hedeflere nadiren ulaşırım. (T) }\end{array}$} & $\mathrm{f}$ & 4 & 7 & 26 & 48 & 53 & \multirow{2}{*}{4,01} & \multirow{2}{*}{1,02} \\
\hline & $\%$ & 2,9 & 5,1 & 18,8 & 34,8 & 38,4 & & \\
\hline \multirow{2}{*}{$\begin{array}{l}\text { Hayatımda karşılaştığım çoğu problemi halletme } \\
\text { konusunda kendimi kabiliyetli görmüyorum. (T) }\end{array}$} & $\mathrm{f}$ & 14 & 9 & 20 & 23 & 72 & \multirow{2}{*}{3,94} & \multirow{2}{*}{1,36} \\
\hline & $\%$ & 10,1 & 6,5 & 14,5 & 16,7 & 52,2 & & \\
\hline \multirow{2}{*}{$\begin{array}{l}\text { Beklenmeyen sorunlar oluştuğunda onları çok iyi } \\
\text { halledemem. }(\mathrm{T})\end{array}$} & $\mathrm{f}$ & 4 & 13 & 16 & 37 & 68 & \multirow{2}{*}{4,10} & 1.11 \\
\hline & $\%$ & 2,9 & 9,4 & 11,6 & 26,8 & 49,3 & & 1,11 \\
\hline Bir şeyler yapma kabiliyetim konusunda kendimi & $\mathrm{f}$ & 5 & 11 & 16 & 23 & 83 & 4,22 & 1.15 \\
\hline güvensiz hissederim. (T) & $\%$ & 3,6 & 8,0 & 11,6 & 16,7 & 60,1 & & \\
\hline
\end{tabular}

Tablo 2 incelendiğinde, ölçekte en yüksek aritmetik ortalamaya sahip olan ifadenin ( $\overline{\mathrm{X}}=4,26)$ ile "bir şey yapmaya karar verdiğimde doğrudan o iş üzerinde çalışmaya başlarım" olduğu görülmektedir. Bu ifadeye katılımcıların \%52,9'u "kesinlikle katıldığını", \%26,8'i "katıldığını", \%14,5'i “orta düzeyde katıldığını”, \%5,1'i "katılmadığını" ve \%0,7'si ise "kesinlikle katılmadığını" belirtmiştir. Yüksek ortalamaya sahip bir diğer ifade ise $(\bar{X}=4,22)$ "bir şeyler yapma kabiliyetim konusunda kendimi güvensiz hissederim" ifadesidir. Bu ifadeye katılımc1ların \%60,1'i “kesinlikle katıldığını", \%16,7'si "katıldığını”, \%11,6's1 "orta düzeyde katıldığını", \%8,0'i "katılmadığını" ve \%3,6'sı ise "kesinlikle katılmadığını" belirtmiştir. Ölçekte yer alan en düşük ortalamaya sahip ifade ise, "hoşlanmadığım bir şeyi yapmak durumunda kaldığımda bitirene kadar o iște israrcı olurum" ifadesidir. Bu ifadeye katılımcıların \%26,8'i “kesinlikle katıldığını", \%23,2'si "katıldığını", \%25,4'ü "orta düzeyde katıldığını", \%14,5'i "katılmadığını" ve \%10,1'i ise "kesinlikle katılmadığını" belirtmiştir. Ölçeğe ilişkin genel ortalama ( $\bar{X}=4,01$ ) olarak belirlenmiştir. Ulusoy (2017) ve Özoğul (2017) 


\section{IIIII)}

Turist Rehberliği Dergisi (TURED) \& Y11. 2020, Cilt. 3, Say1. 1

Journal of Tour Guiding (JOTOG) \& Year. 2020, Volume. 3, Issue. 1

tarafindan yapılan araştırmaların sonuçlarıyla bu araştırma sonucu benzerlik göstermektedir. Çınar (2018) tarafından turizm rehberliği bölümü öğrencileri üzerine yapılan araştırmanın sonucuyla ise kısmen bu çalışmanın sonucu benzerlik göstermektedir. Turist rehberlerinin öz yeterliklerinin iyi seviyede olduğu ifade edilebilir.

Tablo 3: Katılımcıların İş Özerkliği Ölçeğine İlişkin Bulgular

\begin{tabular}{|c|c|c|c|c|c|c|c|c|}
\hline İş Özerkliği Ölçeği & 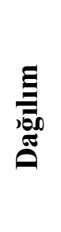 & 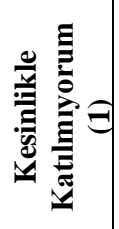 & 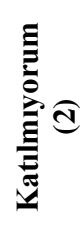 & 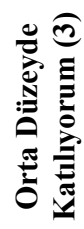 & 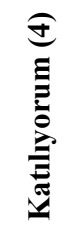 & 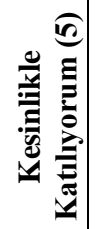 & $\bar{X}$ & ss. \\
\hline \multirow{2}{*}{$\begin{array}{l}\text { İşimi ne şekilde yerine getireceğime dair seçim } \\
\text { yapabiliyorum. }\end{array}$} & $\mathrm{f}$ & 2 & 8 & 27 & 34 & 67 & \multirow{2}{*}{4,13} & \multirow{2}{*}{1,01} \\
\hline & $\%$ & 1,4 & 5,8 & 19,6 & 24,6 & 48,6 & & \\
\hline \multirow{2}{*}{$\begin{array}{l}\text { İşimin amaçları ile ilgili değişiklik } \\
\text { yapabiliyorum. }\end{array}$} & $\mathrm{f}$ & 6 & 10 & 28 & 40 & 54 & \multirow{2}{*}{3,91} & \multirow{2}{*}{1,13} \\
\hline & $\%$ & 4,3 & 7,2 & 20,3 & 29,0 & 39,1 & & \\
\hline \multirow{2}{*}{$\begin{array}{l}\text { İşim gereği belirli aktivitelerin ne zaman } \\
\text { yapılacağına karar veremiyorum. }(\mathrm{T})\end{array}$} & $\mathrm{f}$ & 16 & 23 & 31 & 29 & 39 & \multirow{2}{*}{3,38} & \multirow{2}{*}{1,35} \\
\hline & $\%$ & 11,6 & 16,7 & 22,5 & 21,0 & 28,3 & & \\
\hline \multirow{2}{*}{$\begin{array}{l}\text { İsim ile ilgili faaliyetleri sıraya koyma } \\
\text { hususunda herhangi bir yetkim yok. }(\mathrm{T})\end{array}$} & $\mathrm{f}$ & 1 & 12 & 28 & 31 & 66 & 4,08 & 1,04 \\
\hline & $\%$ & 0,7 & 8,7 & 20,3 & 22,5 & 47,8 & \multirow{2}{*}{\multicolumn{2}{|c|}{$\mathbf{3 , 8 7}$}} \\
\hline $\mathbf{G e}$ & & & & & & & & \\
\hline
\end{tabular}

İş özerkliği ölçeğine ilişkin ifadeler incelendiğinde, en yüksek ortalamaya sahip ifade $(\bar{X}=4,13)$ ile "işimi ne şekilde yerine getireceğime dair seçim yapabiliyorum" olmuştur. Bu ifadeye katılımcıların \%48,6's1 "kesinlikle katıldığını", \%24,6's1 "katıldığını", \%19,6's1 "orta düzeyde katıldığını", \%5,8'i "katılmadığını" ve \%1,4’ü ise "kesinlikle katılmadığını" belirtmiştir. Ölçekteki en düşük ortalamaya sahip $(\bar{X}=3,38)$ ifade ise "işim gereği belirli aktivitelerin ne zaman yapılacağına karar veremiyorum (T)" olmuştur. İş özerkliği ölçeğine ilişkin genel ortalama $(\overline{\mathrm{X}}=3,87)$ olarak belirlenmiştir. Bu doğrultuda, turist rehberlerinin iş özerkliklerinin iyiye yakın olduğu söylenebilir.

Tablo 4: Öz Yeterlik ile İş Özerkliği Arasındaki Korelasyon Matrisi

\begin{tabular}{|c|c|c|c|}
\hline Ölçekler & $\mathbf{r} / \mathbf{p}$ & Öz Yeterlik & İş Özerkliği \\
\hline \multirow{2}{*}{ Öz Yeterlik } & $\mathrm{r}$ & 1 & $0,429^{* *}$ \\
\cline { 2 - 4 } & $\mathrm{p}$ & - & 0,000 \\
\hline \multirow{2}{*}{ İş Özerkliği } & $\mathrm{r}$ & $0,429^{* *}$ & 1 \\
\cline { 2 - 4 } & $\mathrm{p}$ & 0,000 & - \\
\hline
\end{tabular}

Araştırmada turist rehberlerinin öz yeterlikleri ile iş özerklikleri arasındaki ilişkiye dair Pearson korelasyon analizi sonuçları Tablo 4'te sunulmuştur. Pearson korelasyon analizinin sonuçlarına göre, öz yeterlik ile iş özerkliği arasında pozitif yönde ve anlamlı ilişki bulunmuştur. $\mathrm{Bu}$ kapsamda, öz yeterlikle ile iş özerkliği $(\mathrm{r}=0,429 ; \mathrm{p}<0,01)$ arasında pozitif, orta düzeyde ve anlamlı bir ilişki bulunmuştur $(0,40<\mathrm{r}<0,60)$. Sousa, Coelho ve GuillamonSaorin (2012) tarafından banka çalışanları üzerine yapılan çalışmanın bulguları, bu sonuçları destekler niteliktedir. Araştırmacılar, öz yeterlik ile iş özerkliği arasında $(\mathrm{r}=0.277 ; \mathrm{p}<.01)$ pozitif, anlamlı ve düşük düzeyde bir ilişki olduğunu ortaya koymuşlardır. Tilfarlığlu ve Çiftçi (2011), 250 üniversite hazırlık sınıfı öğrencisi üzerine yaptıkları araştırmada öz yeterlik ile iş özerkliği arasında $(\mathrm{r}=0.667 ; \mathrm{p}>.01)$ pozitif, anlamlı ve yüksek düzeyde bir ilişki bulunmuştur. Dolayısıyla bu araştırmanın sonucuyla diğer araştırma sonuçları büyük ölçüde benzeşmektedir. 


\section{IIIII)}

Turist Rehberliği Dergisi (TURED) \& Y11. 2020, Cilt. 3, Sayı. 1

Journal of Tour Guiding (JOTOG) \& Year. 2020, Volume. 3, Issue. 1

Tablo 5: Öz Yeterliliğin İş Özerkliği Üzerindeki Etkiye Ait Basit Doğrusal Regresyon Analizi Sonuçları

\begin{tabular}{|c|c|c|c|c|c|}
\hline Bağımsız Değişken & bj & $\mathbf{S}(\mathbf{b j} \mathbf{j})$ & $\mathbf{t}$ & p & ANOVA \\
\hline Sabit & 1,844 & 0,372 & 4,953 & 0,000 & \multirow{2}{*}{$\begin{array}{l}\mathrm{F}=30,724 \\
\mathbf{p}=\mathbf{0 , 0 0 0}\end{array}$} \\
\hline Öz Yeterlik & 0,506 & 0,091 & 5,543 & 0,000 & \\
\hline
\end{tabular}

Yapılan regresyon analizinde "iş özerkliği” bağımlı değişken, "öz yeterlik" ise bağımsız değişken olarak analiz edilmiştir. Tablo 5 'teki sonuçlara göre, turist rehberlerinin öz yeterlik ile iş özerkliği arasındaki basit doğrusal regresyon modeli anlamlı bulunmuştur $(\mathrm{F}=30,724 ; \mathrm{p}<0,05)$. Tablo 5 'teki regresyon analizi sonucundan elde edilen bulgulara göre, turist rehberlerinin öz yeterliklerinin iş özerklikleri üzerinde önemli bir etkisi olduğu ifade edilebilir $(p<0,05)$. Bağımlı değişken (iş özerkliği) ile bağımsız değişken (öz yeterlik) arasındaki ilişkiye ait basit doğrusal regresyon modeli şu şekildedir: İÖ=1,844 + 0,506.ÖY

Kurulan söz konusu modele göre, öz yeterlikte olan bir birim artış turist rehberlerinin iş özerkliklerinde 0,506 artış yaratmaktadır. Turist rehberlerinin öz yeterlik $(\mathrm{p}=0,000)$ düzeyi arttıkça iş özerklikleri ( $\mathrm{p}=0,000)$ pozitif ve olumlu yönde artmaktadır. Bu sonuca göre, "H1: Turist rehberlerinin öz yeterlik algıları iş özerklik algılarını anlamlı düzeyde pozitif yönde etkilemektedir" şeklinde geliştirilmiş olan hipotez desteklenmiş̧ir.

\section{Sonuç ve Öneriler}

$\mathrm{Bu}$ araştırmanın amacı turist rehberlerinin öz yeterlik seviyelerinin iş özerkliği algıları üzerindeki etkisini ortaya koymaktır. Araştırmaya 61 kadın, 77 erkek eylemli turist rehberi katılmıştır. Araştırma kapsamında ölçekler incelendiğinde, turist rehberlerinin öz yeterlik seviyeleri ve iş özerklik algılarının orta düzeyin oldukça üzerinde, iyiye yakın olduğu söylenebilir. Araştırmada değişkenler arasında ilişkiler olduğu ortaya çıkmıştır. Genel olarak değerlendirildiğinde, turist rehberlerinin öz yeterlik düzeylerinin ortalamanın üzerinde olması meslek açısından sevindirici bir durumdur. Bunun nedeni, turist rehberlerinin icra ettikleri meslekleri sevmeleri, mesleğe, çalıştıkları acentalara ve turistlere katkı sunmaya istekli olmaları olarak açıklanabilir. Bu sonuçlar ayrıca turist rehberlerinin mesleki tutumlarının olumlu; iş doyumu düzeylerinin iyi ve kendilerini işleriyle özdeşleşebildiklerini de göstermektedir. Bunun yanı sıra elde edilen bulgular, rehberlerin işten ayrılma niyetlerinin az olduğunu, turist rehberliği mesleğinde kariyerlerine devam etmeye istekli olduklarını da göstermektedir. Turist rehberliği, rehberin yalnız olarak icra ettiği bir meslektir. Acenta, grubu turist rehberine teslim eder, rehber de sahip olduğu kişilik özellikleri, bilgi donanımları, liderlik vasıfları vb. değişkenlere göre turu yönetir. Bunu her ne kadar şoför, muavin ve tur lideri veya acenta yetkilisi ile birlikte yapıyor gibi görünse de aslında tüm bu süreçte rehber tek başınadır. Rehber, tüm anlatımları yapar, zamanı ayarlar, konaklama, restoran ve mola yerleri ile ilgili bütün iletişimden sorumludur. Tüm bunları yaparken rehber, özgür davranmak ister. Tüm iş akışı ve iş sürecinin yönetilmesi, bu işin eğitimini almış ve uygulamasını da yapmış olan turist rehberleri için hayati öneme sahiptir. Bunun nedeni turist rehberi, tur süresince kendini bask1 altında hissedip özgür kararlar alamazsa turdan zevk alamaz ve bilgi ve deneyimlerini doğru ve etkili bir şekilde turistlere aktaramaz. Bu durum, acentanın müşteri kaybına, ülkelerin imajlarının zedelenmesine, yeterli ve etkili yerel ve ulusal tanıtımların yapılamamasına neden olabilir. Dolayısıyla turist rehberlerinin özerkliğin/ iş özgürlüğünün olmaması aslında onların becerilerini de bir biçimde sınırlandırmalarına sebebiyet vermektedir. Buna bağlı olarak, rehberin olumsuz davranışlar sergilemesi ihtimalinin ortaya çıkmasına neden olabilir. Bu nedenle turist rehberlerinin öz yeterlikleri, iş özerklikleri, iş doyumları, mesleki tutumları vb. konular üzerine sıklıkla araştırmalar yürütülmelidir. $\mathrm{Bu}$ 
kapsamda turist rehberlerinin öz yeterliklerini geliştirmek için belirli aralıklarla uygulama gezileri yapılmalı ve bu konudaki eksiklikler giderilmelidir. Ayrıca öz yeterlik konusunda turist rehberlerinin sık sık farklı kaynaklardan kitap, dergi, makale gibi kaynakları okumaları kişisel gelişimlerine katkı sunabilir.

İş özerkliği noktasında ise, acentalar tarafindan turist rehberlerinin tur süresince karar alıp uygulayabilecek düzeyde yetkilerinin olması ve daha fazla inisiyatif almaları sağlanabilir. Ayrıca, rehberlerin aldıkları/alacakları kararlarda özgür davranmaları teşvik edilebilir. Böylelikle acentaların üzerindeki yük azalacağından, acentalar kendi asli işlerine yoğunlaşıp kalan ekstra zamanlarda müşterilerine daha iyi hizmet sunabilirler. Ayrıca hem kendilerine hem de ailelerine daha fazla zaman ayırabilir ve stres düzeylerini en aza indirebilirler.

\section{Kaynakça}

Akgündüz, Y. (2012). Konaklama İşletmelerinde Otantik Liderlik ve Öz Yeterlilik Arasındaki İlişkinin Analizi, Yayımlanmamış Doktora Tezi, İzmir: Dokuz Eylül Üniversitesi, Sosyal Bilimler Enstitüsü.

Aksoy, M. (2019). Beşeri Sermaye, Sosyal Sermaye ve Öz Yeterliliğin Restoran Performansına Etkisi, Yayımlanmamış Yüksek Lisans Tezi, Kırklareli: Kırklareli Üniversitesi, Sosyal Bilimler Enstitüsü.

Amburgey, W.O.D. (2005). An Analysis of the Relationship Between Job Satisfaction, Organizational Culture and Perceived Leadership Characteristics, Unpublished Ph.D. Thesis, New York: University of Central Florida.

Ap, J., and Wong, K. K. (2001). Case Study on Tour Guiding: Professionalism, Issues and Problems. Tourism Management, 22 (5), 551-563.

Aşkar, P. ve Umay, A. (2001). İlköğretim Matematik Öğretmenliği Öğrencilerinin Bilgisayarla İlgili Öz-Yeterlik Algısı. Hacettepe Üniversitesi Eğitim Fakültesi Dergisi, 21 (21), 1-8.

Blegen, M. A. (1993). Nurses' Job Satisfaction: A Meta-Analysis of Related Variables. Nursing Research, 42 (1), 36-41.

Bosscher, R. J. and Smit, J. H. (1998). Confirmatory Factor Analysis of the General SelfEfficacy Scale. Behaviour Research and Therapy, 36 (3), 339-343.

Bowen, E. and Lawler, E. E. (1992). The Empowerment of Service Workers: What, Why and When. Sloan Management Review, 33, 31-39.

Breaugh, J. A. (1999). Further Investigation of the Work Autonomy Scales: Two Studies. Journal of Business and Psychology, 13 (3), 357-373.

Çınar, B. (2018). Turizm Rehberliği Bölümü Öğrencilerinde Genel Özyeterlilik Algısı, Mesleki Kaygı ve Mesleği Yapma Niyeti İlişkisi, Yayımlanmamış Yüksek Lisans Tezi, Mersin: Mersin Üniversitesi, Sosyal Bilimler Enstitüsü.

Dude, D. J. (2012). Organizational Commitment of Principals: The Effects of Job Autonomy, Empowerment and Distributive Justice, Unpublished Doctoral Thesis, The University of Iowa: USA.

Ercan, A. (2014). Sessizleşen Örgütlerde Öz Yeterlilik Algısının Rolü: Alanya'daki Konaklama İşletmeleri Üzerine Bir Araştırma, Yayımlanmamış Yüksek Lisans Tezi, Antalya: Akdeniz Üniversitesi, Sosyal Bilimler Enstitüsü.

Eryılmaz, G. (2018). Rekreatif Etkinliklere Katılan Bireylerin Akış Deneyimleri, Pozitif ve Negatif Duygu Durumları, Öz Yeterlilikleri ve Yaşam Doyumları İlişkisi, Yayımlanmamış Doktora Tezi, Mersin: Mersin Üniversitesi, Sosyal Bilimler Enstitüsü.

Gray, G. and Pratt, R. (1989). Accountability: Pivot of Professionalism, In Issues in Australian Nursing (Ed: G. Gray and R. Pratt). 149-161, Melbourne: Churchill Livingston. 
Griffin, M. A., Neal, A. and Parker, S. K. (2007). A New Model of Work Role Performance: Positive Behavior in Uncertain and Interdependent Contexts. Academy of Management Journal, 50 (2), 327-347.

Hackman, J. R., and Oldham, G. R. (1975). Development of the Job Diagnostic Survey. Journal of Applied Psychology, 60, 159-170.

Hakimi, N., van Knippenberg, D., and Giessner, S. (2010). Leader Empowering Behaviour: The Leader's Perspective. British Journal of Management, 21, 701-716.

Hart, G., and Rotem, A. (1995). The Clinical Learning Environment: Nurses' Perceptions of Professional Development in Clinical Settings. Nurse Education Today, 15 (1), 3-10.

Hartline, M. D., Maxham, J. G. III, and McKee, D. O. (2000). Corridors of Influence in the Dissemination of Customer-oriented Strategy to Customer Contact Service Employees. Journal of Marketing, 64, 35-50.

Kalayc1, Ş. (2017). SPSS Uygulamalı Çok Değişkenli İstatistik Teknikleri, (8. Baskı). Ankara: Dinamik Akademi Dağıtım.

Kendir, H. (2017). Otel İşletmelerinde Çalışanların Kariyer Tatmini ve Kariyer Bağlllığı İlişkisinde Öz Yeterliliğin Rolü, Yayımlanmamış Doktora Tezi, Nevşehir: Nevşehir Hacı Bektaş Veli Üniversitesi, Sosyal Bilimler Enstitüsü.

Kerse, G. (2017). İş Becerikliliği (Job Crafting) Ölçeğini Türkçe'ye Uyarlama ve Duygusal Tükenme ile İlişkisini Belirleme. İşletme Araştırmaları Dergisi, 9 (4), 283-304.

Keskin, E. (2017). Otel İşletmeleri Yöneticilerinin Öz Yeterliliklerinin Karar Verme Stillerine Etkisinde Yönetsel Güçlülüğün Aracılık Rolü, Yayımlanmamış Doktora Tezi, Nevşehir: Nevşehir Hacı Bektaş Veli Üniversitesi, Sosyal Bilimler Enstitüsü.

Lin, C. T., Wang, K. C. and Chen, W. Y. (2008). Female Tour Leaders as Advertising Endorsers. The Service Industries Journal, 28 (9), 1265-1275.

Morrison, E. W. and Phelps, C. C. (1999). Taking Charge at Work: Extrarole Efforts to Initiate Workplace Change. Academy of Management Journal, 42 (4), 403-419.

Özoğul, G. (2017). Profesyonel Turist Rehberlerinin Kişilik Özellikleri ile Mesleki Bağlllık Arasındaki İlişki Üzerine Psikolojik Sermayenin Aracılık Etkisi, Yayımlanmamış Doktora Tezi, Aydın: Adnan Menderes Üniversitesi, Sosyal Bilimler Enstitüsü.

Pajares, F. (1996). Self-Efficacy Beliefs in Academic Settings. Review of Educational Research, 66 (4), 543-578.

Pratiwi, K. R. I., Saleh, C. and Sentanu, I. G. E. P. S. (2019). Policy Implementation of Tour Guides License in Maintaining the Quality of Tourism in Bali Province. Journal of Indonesian Tourism and Development Studies, 7 (3), 175-183.

Reisinger, Y. and Steiner, C. (2006). Reconceptualising Interpretation: The role of Tour Guides in Authentic Tourism. Current Issues in Tourism, 9 (6), 481-498.

Sarı, B. (2017). Otel İşletmelerinde Yaşam Doyumunun İş Tatminini Etkilemesi ve Öz Yeterliliğin Aracılık Rolü Üzerine Bir Araştırma, Yayımlanmamış Yüksek Lisans Tezi, İstanbul: İstanbul Ticaret Üniversitesi, Sosyal Bilimler Enstitüsü.

Slemp, G. R., Kern, M. L. and Vella-Brodrick, D. A. (2015). Workplace Well-being: The Role of Job Crafting and Autonomy Support. Psychology of Well-being, 5 (1), 1-17.

Sousa, C. M. P., Coelho, F. and Guillamon-Saorin, E. (2012). Personal Values, Autonomy, and Self-Efficacy: Evidence from Frontline Service Employees. International Journal of Selection and Assessment, 40 (2), 159-170. Doi: 10.1111/j.1468-2389.2012.00589.x.

Spector, P. E. (1986). Perceived Control by Employees: A Meta-analysis of Studies Concerning Autonomy and Participation at Work. Human Relations, 39 (11), 1005-1016.

Şahin, F. ve Gürbüz, S. (2012). Kültürel Zekâ ve Öz-Yeterliliğin Görev Performansı ve Örgütsel Vatandaşlık Davranışı Üzerinde Etkisi: Çokuluslu Örgüt Üzerinde Bir Uygulama. İs, Güç Endüstri İlişkileri ve İnsan Kaynakları Dergisi, 14 (2), 123-140. 


\section{IIIII)}

Turist Rehberliği Dergisi (TURED) \& Yıl. 2020, Cilt. 3, Sayı. 1

Journal of Tour Guiding (JOTOG) \& Year. 2020, Volume. 3, Issue. 1

Tarakçı, U. A. (2009). Türk Özel Sektör Yöneticilerinin Çatışmaları Çözmede Kullandıkları Stiller ve Bu Stillerin Öz Yeterlilik Algılamasıyla İlişkisi, Yayımlanmamış Yüksek Lisans Tezi, Balıkesir: Balıkesir Üniversitesi, Sosyal Bilimler Enstitüsü.

Tı1farlığlu, F. Y. ve Çiftçi, F. Ş. (2011). Supporting Self-Efficacy and Learner Autonomy in Relation to Academic Success in EFL Classrooms (A Case Study). Theory and Practice in Language Studies, 1 (10), 1284-1294.

Tsaur, S. H. and Lin, W. R. (2014). Hassles of Tour Leaders. Tourism Management, 45, 28 38.

Turamberk Özerden, S. (2010). Turizm İşletmelerinde Çalışan Bireylerin Öz Yeterlilik Algılarının Psikolojik Şiddet Olgusu Üzerindeki Etkisi: KKTC'de Bir Uygulama, Yayımlanmamış Yüksek Lisans Tezi, Antalya: Akdeniz Üniversitesi, Sosyal Bilimler Enstitüsü.

TUREB (2020). Resmi Rehber İstatistikleri, http://tureb.org.tr/tr/RehberIstatistik/ (Erişim Tarihi: 08.01.2020).

Uçar, Ö. (2018). İşgörenlerin Dönüşümcü ve Etkileşimci Liderlik Tarzları Algılamaları ile Öz Yeterlilikleri Arasındaki İlişkide Yöneticiye Duyulan Güvenin Aracılık Rolü: Bir Zincir Otel Uygulaması, Yayımlanmamış Doktora Tezi, Antalya: Akdeniz Üniversitesi, Sosyal Bilimler Enstitüsü.

Ulusoy, H. (2017). Turist Rehberlerinin Kültürel Zekâ Düzeyi ve Öz yeterlilik İnançlarının Hizmet Sunumuna Etkisi, Yayımlanmamış Yüksek Lisans Tezi, Balıkesir: Balıkesir Üniversitesi, Sosyal Bilimler Enstitüsü.

Üstüner, M., Demirtaş, H., Cömert, M., ve Özer, N. (2009). Ortaöğretim Öğretmenlerinin ÖzYeterlik Algiları Secondary School Teachers' Self-Efficacy Beliefs. Mehmet Akif Ersoy Üniversitesi Ĕ̈itim Fakültesi Dergisi, 9 (17), 1-16.

WFTGA. (2020). What is a Tourist Guide, Retrieved from, http://www.wftga.org/touristguiding/what-tourist-guide (03.02.2020)

Yılmaz, T. (2018). Stratejik Yönetim Açısından Personel İlișkileri Yönetimi: Turizm İşletmelerinde İlişki Yönetiminin Personel Memnuniyetine Etkisinde İş Özerkliğinin Aracı Rolü, Yayımlanmamış Yüksek Lisans Tezi, Antalya: Akdeniz Üniversitesi, Sosyal Bilimler Enstitüsü.

\section{ETIKK ve BILLIMSEL ILKELER SORUMLULUK BEYANI}

Bu çalışmanın tüm hazırlanma süreçlerinde (veri toplama, yazım vb.), tüm etik kurallara ve bilimsel atıf gösterme ilkelerine riayet edildiğini, herhangi bir hataya mahal vermemek için yayımdan önce makalenin bir intihal programı aracıllğıyla da kontrol edildiğini yazarlar beyan eder. Ayrıca yazarlar aşağıda sıralanan hususları kabul etmiştir:

1. Çalışmada yer alan ve kullanılan tüm kaynaklara, bilimsel araştırma yöntemleri ve etik ilkeler doğrultusunda atıf yapılmıştır.

2. Çalışmada tüm yazarların akademik-bilimsel olarak doğrudan ve ortak katkısı vardır.

3. Bu çalışma, yazarların özgün bir çalı̧̧masıdır.

4. Bütün yazarlar dergiye gönderilen makaleyi görmüș ve sonuçlarını onaylamıștır.

5. Çalışmada kullanılan denek/deneklere ilişkin herhangi bir etik ihlal yapılmamış, kullanılan tüm veri toplama yöntemlerinde bilimsel etik ilkelere göre hareket edilmiştir.

6. Calıșma daha önceden bilimsel bir toplantıda sunulan özet veya bu çalıșmanın daha kısa hali ise, makalede bu durum belirtilmiştir.

7. Çalışmada, hiçbir suç unsuru veya kanuna aykırı ifade bulunmamakla birlikte, araştırma yapılırken kanuna aykırı herhangi bir yöntem kullanılmamış olup, çalışma ile ilgili tüm yasal izinler alınmış ve etik kurallara uygun hareket edilmiştir.

Aksi bir durumun tespiti halinde Turist Rehberliği Dergisi’nin hiçbir sorumluluğu olmayıp, tüm sorumluluk makale yazarlarına aittir.

Tarih $\quad: 31 / 05 / 2020$

Sorumlu Yazar $\quad$ : Arş. Gör. Ali KABAKULAK 